\title{
Characteristics of animal protection non-governmental organizations in the state of Paraná, Brazil: qualitative-quantitative analysis
}

\author{
[Características das organizações não-governamentais de proteção animal do estado do Paraná, \\ Brasil: análise quali-quantitativa]
}

\section{"Scientific Article/Artigo Científico"}

\author{
Dariane Cristina Catapan*, Tâmara Duarte Borges, Manoella Müller, Cláudia Turra Pimpão
}

Post-Graduation Program in Animal Science, Pontifical Catholic University of Paraná, Curitiba-PR, Brazil.

*Corresponding author/autora para correspondência: E-mail: darianecatapan@yahoo.com.br

\begin{abstract}
This study describes characteristics of a sample of 80 dog and cat non-governmental organizations (NGOs), in order to present an overview for academic and scientific knowledge. As statistical analysis, we used Content Analysis, t-test and z-test to find the confidence interval for the average time of the NGOs' existence, and Fisher's exact test to compare the ratio for NGOs with/without shelters. The NGOs are located in 49 of the 399 municipalities of Paraná (12.28\%). Curitiba presented the largest number of NGOs (n=16), representing $20 \%$ of the total organizations. The average time of existence of NGOs in Paraná is $8.75 \pm 7.14$ years. The oldest NGO was created in 1972, and the most recent one in 2020. Main source of income of the organizations is donations, in $58.56 \%(\mathrm{n}=65)$ of the cases; only $7.21 \%(\mathrm{n}=7)$ of them reported having received government support. Also, $48.75 \%(n=39)$ are regulated NGOs, and 56.25\% $(n=45)$ of them do not have shelters for reception and housing of dogs and cats. This study concluded that the actions of NGOs supported by civil society, community, and government are fundamental to mitigate dog overpopulation.
\end{abstract}

Keywords: shelter; adoption; dogs; cats; managers; mapping.

\section{Resumo}

Este estudo descreve características de uma amostra de 80 organizações não-governamental (ONGs) de cães e gatos, com o objetivo de apresentar um panorama geral para conhecimento acadêmico-científico. Como análise estatística foi utilizada a Análise de conteúdo, Teste $t$ e Teste $\mathrm{Z}$ para determinar o intervalo de confiança do tempo médio de existência das ONGs, e Teste Exato de Fisher para comparar proporções de ONGs com e sem abrigo. As ONGs estão localizadas em 49 dos 399 municípios do Paraná (12,28\%). Curitiba apresentou o maior número de ONGs $(n=16)$, representando $20 \%$ do total de organizações. $\mathrm{O}$ tempo médio de existência das ONGs no Paraná é de 8,75 $\pm 7,14$ anos. A ONG mais antiga foi criada em 1972 e a mais recente em 2020. A principal fonte de renda das organizações é através de doações, em $58,56 \%(\mathrm{n}=65)$ dos casos; apenas 7,21\% $(\mathrm{n}=7)$ deles relataram ter recebido apoio governamental. Além disso, $48,75 \%(n=39)$ são ONGs reguladas, e $56,25 \%(n=45)$ delas não possuem abrigo para acolhimento e alojamento de cães e gatos. Este estudo concluiu que as ações das ONGs apoiadas pela sociedade civil, comunidade e governo são fundamentais para mitigar a superpopulação de cães.

Palavras-chave: abrigo; adoção; cães; gatos; gestores; mapeamento.

\section{Introduction}

In 1950, the largest international animal protection NGO of that time, the World Federation for Animal Protection - World Federation for the Protection of Animals (WFPA) was created. In 1959 the International Society for the Protection of Animals (ISPA) was formed, in 1981 the WFPA and ISPA merged to form the World Society for the Protection of Animals World Society for the Protection of Animal 
(WSPA), and in 2014 WSPA became WPA World Animal Protection, with the proposal of work: "put an end to the unnecessary suffering of animals, inspiring people to permanently change their lives" (WPA, 2017).

Regarding the ways of acting, in 1985, WSPA launched a campaign to ban bullfighting in cities in France and Spain. In the 1990s, he acted to ban bear dancing in Greece, Turkey and India. In India, the NGO financed a sanctuary for bears previously used in trade. Currently, WPA works on animals in communities, farm animals, wild animals, education, animals in disaster situations and global animal protection (WPA, 2017).

The first Brazilian entity, related to animal protection, was founded in 1895 , called the International Union for the Protection of Animals (UIPA), and was responsible for the institution of the animal protection movement in Brazil in the $19^{\text {th }}$ century (UIPA, 2017).

The role of animal protection nongovernmental organizations (NGOs) is important to control the population density of dogs and cats, as currently overcrowding of these animals, especially dogs, is a common problem in urban centers (Moutinho et al., 2015), as it is in Paraná and its municipalities (Molento et al., 2005; Catapan et al., 2014).

São José dos Pinhais, one of the cities in the metropolitan region of Curitiba, has the animal: human ratio of 1: $2.47(\operatorname{dogs})$ and 1: 15.32 (cats) (Catapan et al., 2015). However, the capital of Paraná, Curitiba, has a dog: human ratio of 1: 4 (Biondo et al., 2007). Other municipalities, such as Piraquara and Pinhais, have the proportion of dogs: 1: 2.3 (Branco et al., 2007) and 1: 3 (Martins et al., 2008), respectively. The proportion in Brazil of cat: human found in other studies were, 1: 5.2 (Molento et al., 2007) and in Curitiba, 1: 86.38 in apartments (Serafini et al., 2008). This means that the proportions animal: human beings reflect the reality observed in urban centers, the situation of abandonment of animals.

Responsibility for solving the issue of abandoned dogs involves more than one social actor, demonstrating the relevance of public policies for dogs and cats. The response to the problem of abandoned animals is interdisciplinary and should be divided between society, represented minimally by animal protection NGOs, veterinarians, animal owners, and public authority, represented by its public health organs and various secretariats (Santana and Oliveira,
2006; Bortoloti and D'Agostino; 2007, OIE, 2013).

Still in relation to the abandonment, some papers (Barrera et al., 2008; Paploski et al., 2012; Protopopova et al., 2012) discuss about the high number of dogs abandoned throughout the world and, consequently, supported by actions of control of overpopulations. According to the World Health Organization (WHO), there are more than 20 million dogs and 10 million abandoned cats in Brazil (ANDA, 2017).

In an attempt to mitigate the problems related to the abandonment of animals and overpopulation of dogs and cats, one of the strategies is topopulation estimates of dogs and cats, with the aim of presuming the amount of domestic animals that exist, according to the size of the human population. But this is not the case with NGOs. There is a shortage of information about NGOs in Brazil, and especially in the state of Paraná.

The objective of the present work was to map the NGOs of dogs and cats of the state of Paraná, as well as to know the perception of the managers about the relationship of NGOs and the situation of dogs and cats in public roads, besides characterizing the organizations in relation to the activities carried out and support received.

\section{Materials and Methods}

The number of animal protection NGOs sampled per stratum was defined considering the size of the population of said mesoregion, according to the last census conducted in 2010 (IBGE, 2011), according to Table 1 . In this way, the sample is defined as stratified, in a representative manner, in distribution and quantity.

It is assumed that in the more populous mesoregions, because the human-animal relationship is directly influenced (FAO et al., 2003), there are more dogs and cats, so more NGOs were sampled. Therefore, the definition of the number of NGOs was considered according to the human population of the municipalities.

The sample intensity was calculated using the Z-Test for proportions, considering the assumptions for its use (Levine, 2008; Larson and Farber, 2010).

$$
n=\frac{\mathrm{Ztab}{ }^{2} \cdot p \cdot q}{E^{2}}
$$

On what: 
Ztab = value of standardized Gaussian distribution (mean equal to zero and standard deviation equal to 1) for the level of probability to be tested $\mathrm{p}=$ probability of success of the dichotomous variable of interest $\mathrm{q}=$ probability of failure of the dichotomous variable of interest (1-p)

$\mathrm{E}=$ margin of error to be detected

For Test Z, an alpha $(\alpha)$ of 0.05 , that is, a result with $95 \%$ probability was considered. This indicates the level of reliability in the conclusions or interpretations of the results obtained.

In the same test a margin of error of $10 \%$ of difference between the proportions was adopted. Thus, with 80 samples (NGOs) it was possible to find $10 \%$ difference between two proportions, at 95\% probability.

Table 1. Total population of Paraná according to geographic mesoregions (research strata) and number of animal protection of non-governmental organizations (NGOs) sampled.

\begin{tabular}{lcc}
\hline Stratum & $\begin{array}{c}\text { Total Resident } \\
\text { Population }\end{array}$ & $\begin{array}{c}\text { Number of } \\
\text { NGOs sampled }\end{array}$ \\
\hline West Central & 334.125 & 1 \\
Southeast & 404.779 & 2 \\
Southwest & 497.127 & 4 \\
South Central & 544.190 & 4 \\
North Pioneer & 546.224 & 5 \\
Northwest & 678.319 & 5 \\
East Central & 689.279 & 5 \\
West & 1.219 .558 & 8 \\
North Central & 2.037 .183 & 16 \\
Metropolitan & 3.493 .742 & 30 \\
of Curitiba & 10.444 .526 & 80 \\
Paraná - Total &
\end{tabular}

Source: Adapted from IBGE (2011).

Due to the sampling intensity required for each stratum, NGOs were surveyed in the state of Paraná following five methodologies, in which confidentiality is ensured by the omission of the names of the NGOs sampled.

The research was started using a database of NGOs by state of Brazil (NGOs Brazil, 2018). By selecting the state in question it was possible to check an online list with 26 NGOs located in different mesoregions.

Since the number of samples found was insufficient, the second methodology of data collection was carried out. Two sites were visited (Globo, 2016; Guia de mídia, 2018) that presented the map of animal protection NGOs $(\mathrm{n}=10)$ and NGOs benefiting from the Nota Paraná $(n=12)$, respectively. Thus, the 22 NGOs were included in the research $(26+22=48)$, always respecting the proportions according to the number of inhabitants of that region.

In order to reach the required sample intensity, we accessed the websites of municipalities in order to find partner NGOs that work in the animal cause, which is the third method of data collection. However, there was a limitation in this search because the situation of NGOs is not regulated.

The number of samples required per stratum was achieved when the fourth methodology was used $(n=32)$, using the search sites (Google) to locate names of NGOs in Paraná. This research had as presupposition the use of terms: "NGO" + "protection" + "animal" + "Curitiba" + "metropolitan region" + "cities" + "PR". This methodology was adapted from Moutinho et al. (2015).

The following information was searched on the website of each NGO: 1 - name of the NGO, 2 - activities developed by the NGO, 3 - location of the city, 4 - classification in the mesoregion of Paraná, 5 - type of support received by the NGO (government, veterinary clinics, companies, people), 6 - the situation of the NGO in relation to regulation (whether or not it has a legal status and national registry of a legal entity - CNPJ), 7 - the source of income (donations, events, provision of services, own resources), 9- existence or not of shelter (in general, not specific for dogs and/or cats), 10 - NGO mission. This information was classified as qualitative $(1,2,3,4,5,6,8,10)$ and quantitative $(7,9)$.

In addition, telephone contacts were made with NGO managers, in cases where there was not enough information on the NGO website, considered the fifth data collection methodology.

Information extracted from sites of animal protection NGOs of Paraná was analyzed, since no national or state records of this nature were identified and in consulted bibliography, no work presented such database related to the census of animal protection NGOs (Moutinho et al., 2015), except management information on the number of NGOs extracted from IBGE (IBGE, 2012).

In order to analyze the qualitative information, the Content Analysis method was used, which consists of grouping the information into categories, according to elements, ideas or expressions with similarities (Moutinho et al., 2015). In addition, the data were interpreted descriptively and / or in graphs. Still on content analysis, Bardin (1977) defines that this method 
aims at the knowledge of variables based on indicators of a sample of messages, which are later classified and counted by repetition frequencies.

The activities carried out by the NGOs were grouped into six categories, based on the information presented on the websites: 1adoption, 2-castration, 3-veterinary treatment, 4collection, 5-complaint handling and 6-awareness about responsible custody. Through the website, some NGOs reported doing more than one activity, totaling six activities, since this variable was not mutually exclusive. In this way, the number of NGOs was divided by the number of activities it carries out ( 1 action, 2 actions, 3 actions or 4 actions).

In the category " 1 action" the following activities were included: adoption, castration, collection (animals being rescued from the streets or in mistreatment situations), treatment (veterinary care, food, and others dispensed to the animal collected). This means that the NGO performs only one out of five activities.

In the "2 actions" category, the different activities carried out by the NGOs were: adoption and responsible custody awareness / complaint handling and castration / complaint handling and responsible custody awareness / castration and adoption / castration and responsible custody awareness / recollection and adoption / recollection and castration / recollection and treatment / treatment and adoption / treatment and complaint handling.

In the category "3 actions" the activities were: castration, treatment and adoption / recollection, castration and adoption / recollection, treatment and adoption. Finally, in the category "4 actions", the following activities were described: recollection, treatment, castration and adoption.

In order to define the average time of existence of the NGOs in Paraná, T test was used. To determine the confidence interval of small samples means $(p=0.05)$, the Z-Test was used, and to compare proportions of NGOs with and without shelter, the test used was Fisher's Exact Test (considered $\mathrm{p}<0.05$ for different proportions and $p \geq 0.05$ for equal proportions). The tests were performed by Microsoft ${ }^{\circledR}$ Excel 2013.

Data regarding the existence (or not) of shelters and the founding dates of the NGOs were compared statistically by Fisher's Exact Test and $\mathrm{T}$ test, respectively, with another scientific work called "Canine Adoption Practices: A Comparative Documentary Study between Latin American Institutions", from the authors Cunha and Garcia (2014), who aimed to compare NGOs from different countries, such as Brazil, Mexico and Argentina. The meta-analysis was used to compare the results.

\section{Results and Discussion}

Regarding the city and classification in the mesoregion of Paraná, the 80 NGOs were located in 49 of the 399 municipalities of the state, equivalent to $12.28 \%$ of the municipalities.

The municipality of Curitiba was the one with the largest number of NGOs $(n=16)$, representing $20 \%$ of the total. The municipality of Maringá has five NGOs (6.25\%). In the localities of Cambé, Cascavel, Pato Branco, and Ponta Grossa there are 12 NGOs, with three NGOs in each locality (3.75\%), equivalent to $15 \%$. The same happens with the municipalities of Fazenda Rio Grande, Londrina, Nova Esperança, and Paranavaí, where there are eight NGOs, two in each municipality (2.50\%), equivalent to $10 \%$ of the total evaluated. The other 39 municipalities: Andirá, Arapongas, Arapoti, Araucária, Balsa Nova, Bandeirantes, Campina Grande do Sul, Campo Largo, Campo Mourão, Castro, Cia Norte, Colombo, Colorado, Corbélia, Foz do Iguaçu, Francisco Beltrão, Guarapuava, Guaratuba, Ibiporã, Irati, Ivaiporã, Jacarezinho, Laranjeiras do Sul, Marechal Cândido Rondon, Matinhos, Medianeira, Morretes, Nova Aurora, Nova Londrina, Paranaguá, Pinhais, Pinhão, Piraquara, Quedas do Iguaçu, Santa Mariana, São José Dos Pinhais, São Mateus do Sul, Umuarama and Uraí have one NGO each, representing $48.75 \%$ of the total.

Brazil has 2.242 NGOs related to animal protection and the environment. There are 523 NGOs in the South of Brazil, representing $23.33 \%$. Based on the five methodological forms of NGOs search in this article, it is estimated that in Paraná, there is $3.57 \%(\mathrm{n}=80)$ of the total number of NGOs in Brazil $(\mathrm{n}=2.242)$ and there is $15.30 \%(\mathrm{n}=80)$ of the total number of NGOs in the South of Brazil $(n=523)$.

Regarding the date of foundation, we can see oldest NGOs created in 1972 and NGOs with a recent creation in the year 2016. Figure 1 shows the founding dates of the NGOs sampled.

Most NGOs were founded in the years 2007, 2010, 2011, 2012 and $2013(\mathrm{n}=30)$. There 
is a direct relationship between the growth of NGOs, as of 2006, with the end of the public service of collection and euthanasia of street dogs in December 2005 (Rosa, 2017), the dogcatcher. There's an assumption that NGOs were created in an attempt to support the municipality in controlling the population of dogs, and to avoid the consequences of overpopulation of these animals on the streets.

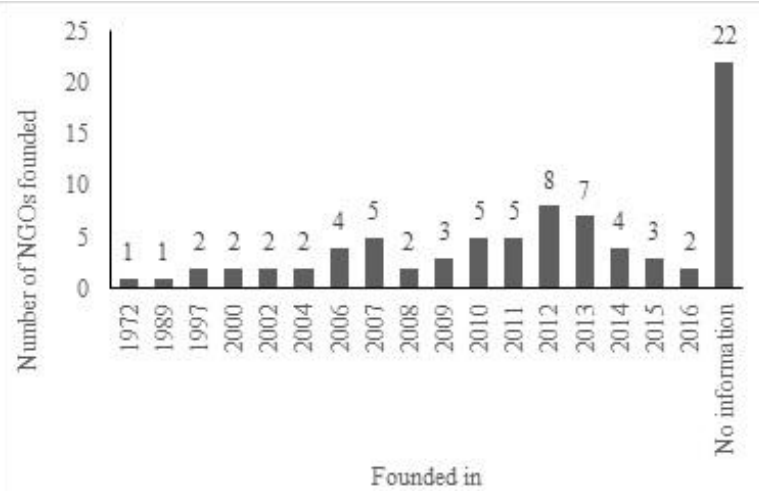

Figure 1. Year of foundation of the 80 nongovernmental organizations (NGOs) sampled.

Although many of the Brazilian NGOs have a limited number of members and different ways of acting, this makes it go beyond the "isolated compassion" of people who collect and treat abandoned animals. The growth of NGOs since 2005 when the cart's activities ended, is also significant in a new context, where animals have been receiving more attention, whether from media vehicles, or from the government, which started to emphasize welfare and the quality of life of the animals (MATOS, 2012).

Cunha and Garcia (2014) observed that founding dates of animal protection NGOs located in Brazil, Mexico and Argentina, range from 1982 to 2006. The average time of existence (8.75 years) of the Paraná NGOs found in this article is statistically similar to that found by Cunha and Garcia (2014) in Brazil, who sampled NGOs with a mean age of 12.5 years, with a standard deviation of 1.73 .

Also on the foundation dates, there are still 22 NGOs (27.50\%) that did not have information on this data. One assumption in the face of this is that NGO sites were probably outdated, without the foundation date information, and this impact on NGO management. Cazzolato (2009) informs that an adequate preparation of the leading NGO manager is necessary, as well as the formation of its mission and objectives, its institutional communication and fundraising are relevant processes for the NGO's management to be efficient and effective.

When analyzing the information of the 58 NGOs (72.50\%), it was observed an average time of foundation of 8.75 years with a standard deviation of 7.14 years. Statistically, there's a confidence interval for the average between 7.15 and 10.34 years.

Comparing the results of this article with data from IBGE (2012), it is worth mentioning that there are 556.846 NGOs in Brazil, from different activities. Brazilian NGOs related to animal protection and the environment represent less than $1 \%(\mathrm{n}=2,242)$ of this total. According to the IBGE (2012), out of these 2.242 NGOs, $60.17 \%(\mathrm{n}=1,349)$ of them were created in the period from 2001 to 2010 , corroborating with the data found in this article, in which $28.75 \%$ of NGOs $(n=23)$ were founded between 2002 and 2010. Also according to the IBGE (2012), a small number of NGOs were created until 1980 ( $\mathrm{n}=$ 71), representing $3.17 \%$ of the total; NGOs created between 1981 and $1990(\mathrm{n}=178)$ represent $7.94 \%$, and $28.72 \%(\mathrm{n}=644)$ of the organizations have been created between 1991 and 2000.

In the case of the NGO's source of income, it occurs in a variety of ways: donations, events, own resources and services (performing castrations) or selling products (clothes, collars, leashes, ties) (Figure 2).

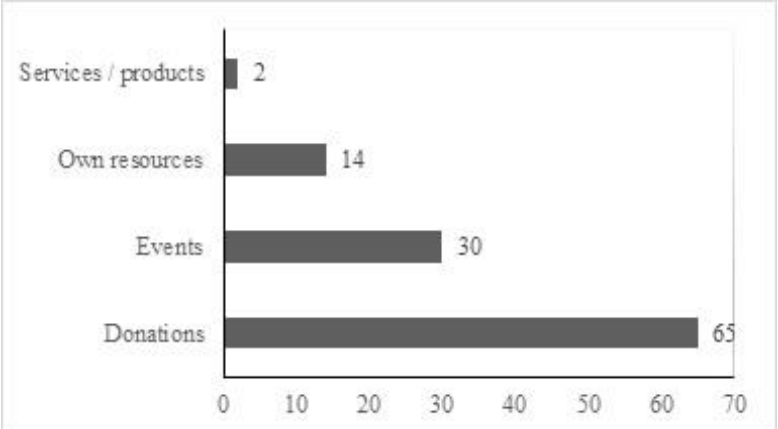

Figure 2. Forms of income source of the nongovernmental organizations (NGOs) sampled.

It can be seen from Figure 2 that most of the NGOs sampled $(\mathrm{n}=65 / 58.65 \%)$ have donations as a source of income. The sample surveyed was 80 NGOs, but the number of indicators in Figure 2 is higher than the sample because the groups are not mutually exclusive, 
meaning that an NGO can belong to one or more categories.

Regarding the existence of support to NGOs, $37.12 \%(\mathrm{n}=36)$ stated that they did not receive any type of support (government, society, companies, veterinary establishments) and only $7.21 \%(\mathrm{n}=7)$ reported receiving government support. $28.87 \%(\mathrm{n}=28)$ of the organizations receive support from society (individuals), $12.37 \%(\mathrm{n}=12)$ support companies, $5.15 \%(\mathrm{n}=$ 5) clinics and veterinary hospitals and $9.28 \%$ did not provide information on the type of support. We note a dilution of the categories, that is, at times some organizations reported receiving more than one type of support. In Cunha and Garcia's study (2014), the support received by the NGOs was provided by the community in general, volunteers, feed companies and the government.

About regulation, $48.75 \%(\mathrm{n}=39)$ are regulated NGOs and $23.75 \%(\mathrm{n}=19)$ are not. Yet $27.50 \%$ of the organizations $(n=22)$ did not present information about this item.

When it comes to the existence of shelter in the area, $43.75 \%(n=35)$ of them have shelter for reception and lodging of dogs and cats, and $56.25 \%(\mathrm{n}=45)$ don't. Comparing this article's proportions of NGOs with or without shelter with the proportions of Cunha and Garcia's work (2014) (three homeless and two sheltered NGOs), using Fisher's Exact Test, one can affirm that the proportions of NGOs with or without shelter are the same as in NGOs in Brazil ( $\mathrm{p}=0.35)$.

The activities carried out, described by the NGOs, were: adoption, treatment, collection, castration, complaint handling and responsible custody awareness, according to Figure 3 . The number of activities exceeded theamount of 80 NGOs, since an NGO can perform more categories of activities.

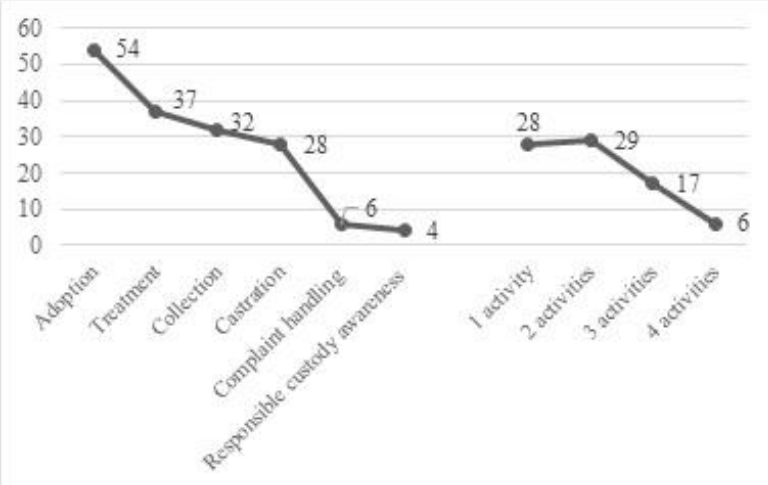

Figure 3. Activities carried out by non-governmental organizations (NGOs) sampled and number of activities (actions) carried out by them.
By analyzing information on NGO activities, considering that 161 was the $n$ sample $(54+37+32+28+6+4$ activities $)$, it can be seen that most (33.54\%) NGOs have adoption as their first activity. Secondly, the most frequent activity was treatment of dogs and cats $(22.98 \%)$. This includes veterinary care, food, and other kinds of care towards the animal collected. In sequence, there are collection activities $(19.88 \%)$ with animals being rescued from the streets or from maltreatment situations. Lastly, castration activities (17.39\%), complaint handling (3.72\%) and responsible custody awareness (2.49\%) are the least common activities.

In terms of the number of actions (activities) carried out by the 80 NGOs (Figure 3), $35 \%$ of organizations reported only one action: adoption $(n=12)$, castration $(n=5)$, recollection $(\mathrm{n}=3)$, treatment $(\mathrm{n}=5)$ and / or complaint handling $(\mathrm{n}=3)$.

The majority (36.25\%) of NGOs carried out two actions, which could be: adoption and responsible custody awareness $(n=1)$ / complaint handling and castration $(\mathrm{n}=1) /$ castration and adoption $(\mathrm{n}=7) /$ castration and responsible custodyawareness $(\mathrm{n}=2) /$ recollection and adoption $(\mathrm{n}=5) /$ treatment and adoption $(\mathrm{n}=6) /$ treatment and complaint handling $(\mathrm{n}=1)$.

In the "3 actions" category, $21.25 \%$ of NGOs reported the following activities: castration, treatment and adoption $(\mathrm{n}=4)$ / collection, castration and adoption $(\mathrm{n}=2) /$ collection, treatment and adoption $(\mathrm{n}=11)$. Finally, in $7.5 \%$ of the cases, in the category "4 actions", NGOs reported doing these activities in a collective way: collection, treatment, castration and adoption $(\mathrm{n}=$ $6)$.

The activities reported by the research NGOs have a connection with the respective missions, which involve veterinary care, rehabilitation, non-abandonment, environmental balance, adoption, environmental education, insertion of animals in homes and the search for animal welfare. However, it was observed that many NGOs repeated the information described as "activities" in the item "mission", which refers to the nature of the organization, to its reason for existing, that objectives and values must be aligned (FILHO, 2006).

\section{Final Considerations}


The scenario and the reality faced by the NGOs of the State of Paraná is challenging, since the greatest difficulty related was the financial problems, even having an important role of solidarity and benefit to society when collecting abandoned animals.

\section{Conflict of interest}

The authors declare there is no conflict ofinterest.

\section{Ethics Committee}

This work was approved by the Research Ethics Committee (CEP) of the Pontifical Catholic University of Paraná (PUCPR), located in the city of Curitiba, Paraná, Brazil, under protocol number 1.797.362 / 2016.

\section{References}

ANDA. Agência de Notícias de Direitos Animais. "Mais de 30 milhões de animais abandonados estão esperando uma chance", diz especialista. Notícia de 20-052017. Disponível em: https://www.anda.jor.br/2017/05/mais-de-30milhoes-de-animais-abandonados-estaoesperando-uma-chance-diz-especialista/. Acessado em: 14 mai. 2018.

Bardin, L. Análise de conteúdo. Portugal: Edições 70, 1977.

Barrera, G; Jakovcevic, A; Bentosela, M. Calidad de vida en perros alojados en refugios: intervenciones para mejorar su bienestar. Suma Psicológica, v. 15, n. 2, p. 337-354, 2008.

Biondo, A.W.; Cunha, G.R.; Silva, M.A.G.; Fuji, K.Y.; Utime, R.A.; Molento, C.F.M. Carrocinha não resolve. Conselho Regional de Medicina Veterinária - PR, 25: 20-21, 2007.

Bortoloti, R.; D'Agostino, R.G. Ações pelo controle reprodutivo e posse responsável de animais domésticos interpretadas à luz do conceito de metacontingência. Revista Brasileira de Análise do Comportamento, 3(1): 17-28, 2007.

Branco, I.D.; Biondo, A.W.; Wouk, A.F.P.F.; Charello, T.; Larsen, H.; Gomig, T.; Uchida, L.; Losso, M.; Barros, A.C.R.; Pimentel, J.S.; Javouroski, E.B.; Ribeiro, K.G. Censo canino em Piraquara, Paraná. In: $15^{\circ}$ Evento de Iniciação Científica, 24-26 de Outubro 2007, Curitiba, Paraná. p. 67.
Catapan, D.C.; Costa, E.D.; Cunha, G.R.; Pimpão, C.T. Impacto do programa de esterilização cirúrgica na população de cães e gatos do município de São José dos Pinhais - PR. Revista Brasileira de Ciência Veterinária, 21(3): 178-182, 2014.

Catapan, D.C.; Vilanova Junior, J.A.; Weber, S.H.; Mangrich, R.M.V.; Szczypkovski, A.D.; Catapan, A.; Pimpao, C.T. Estimativa populacional e programa de esterilização cirúrgica de cães e gatos. Acta Veterinaria Brasilica (UFERSA), 9: 1-14, 2015.

Cazzolato, N.K. As Dificuldades de gestão das Organizações Não-Governamentais. ReFAE

- Revista da Faculdade de Administração e Economia, 1(1): 66-81, 2009.

Cunha, J.G.; Garcia, A. Práticas de adoções caninas: um estudo documental comparativo entre instituições latino-americanas. Revista de Etologia, 13(2): 10-24, 2014.

FAO, OMS, OIE. Organización de las Naciones Unidas para la Agricultura y la Alimentación; Organización Mundial de la Salud; Oficina Internacional de Epizzotias. Conferencia electrónica de FAO/OMS/OIE en salud publica veterinaria y control de zoonosis en países em desarrollo. In: FAO. Veterinary Public Health and Control of Zoonoses in Developing Contries. Roma: FAO, 2003. p. 87-108.

Filho, J.R. Planejamento estratégico da pequena e média empresa: aplicações no setor turístico. Rio de Janeiro: Publit, Soluções Editoriais, 2006.

Guia de mídia. Mapa de ONGs de proteção aos animais. Disponível em: $<$ https://www.guiademidia.com.br/animais/o ngs.htm>. Acesso em: 10 fev. 2018.

Globo. ONGs de animais devem receber créditos do 'Nota Paraná' em junho. Notícia de 03-06-2016. Disponível em: <http://g1.globo.com/pr/parana/noticia/2016/ 06/ongs-de-protecao-animal-comecamreceber-creditos-do-nota-parana.html>. Acesso em: 10 fev. 2018.

IBGE. Instituto Brasileiro de Geografia e Estatística. O estado do Paraná no Censo 2010. Distribuição da população. Censo 2011. Disponível em: <http://www.observatoriodasmetropoles.net/ download/PR_Censo2011.pdf>. Acesso em: 26 jul. 2017. 
IBGE. Instituto Brasileiro de Geografia e Estatística. As fundações privadas e associações sem fins lucrativos no Brasil 2010. Estudos e Pesquisas, Informação Econômica. Rio de Janeiro: 2012. 178 p.

Larson, R.; Farber, B. Estatística aplicada. $4^{\mathrm{a}}$ ed. São Paulo: Pearson Prentice Hall, 2010.

Levine, D.M.; Stephan, D.F.; Krehbiel, T.C.; Berenson, M.L. Estatística: teoria e aplicações. $5^{\text {a }}$ ed. Rio de Janeiro: LTC, 2008.

Martins, C.M.; Amaral, C.H.; Bordignon, R.; Barros, C.C.; Pampuch, R.; Svoboda, W.W.; Biondo, A.W. Estimativa da população de cães e gatos do município de Pinhais - PR, e respectivas ações de saúde pública. In: $35^{\circ}$ Congresso Brasileiro de Medicina Veterinária; 19-22 de Outubro de 2008; Gramado, Rio Grande do Sul.

Matos, L.G. Quando a "ajuda é animalitária" (Dissertação de mestrado). Rio Grande do Sul: Universidade Federal do Rio Grande do Sul, 2012.

Molento, C.F.M; Inoe, A.P.; Rego, M.I.C.; Lago, E.; Meza, S.K.L.; Leme, M.C.; Molento, M.B. Controle populacional de cães e gatos em dez Vilas Rurais do Paraná, Brasil. Arquivos de Ciências Veterinárias e Zoologia da UNIPAR, 8(1): 25-31, 2005.

Molento, C.F.M.; Lago, E.; Bond, G.B. Dog and cat population control in ten Rural Villages, Paraná, Brazil. Archives of Veterinary Science UNIPAR, 12(3): 43-50, 2007.

Moutinho, F.F.B.; Nascimento, E.R.; Paixão, R.L. Percepção da sociedade sobre a qualidade de vida e o controle populacional de cães não domiciliados. Ciência Animal Brasileira, 16(4): 574-588, 2015.

OIE. Organização Internacional de Saúde Animal. Control de las poblaciones de perros vagabundos. In: OIE. Código Sanitario para los Animales Terrestres - 2013. 2013. Disponível em: $<$ http://www.oie.int/es/normasinternacionales/codigo-terrestre/acceso-enlinea/_. Acesso em: 06 jul. 2017.
ONGs Brasil. Distribuição de ONGs por estado do BR. Disponível em: $<$ http://www.ongsbrasil.com.br/default.asp?P $\mathrm{ag}=37 \&$ Estado $=\mathrm{PR} \&$ Cidade $=\& \mathrm{ONG}=\&$ Tipo $=$ Animais $\&$ Btn $=$ Pesquisar $+\mathrm{ONG}>$. Acesso em: 10 fev. 2018.

Paploski, I.A.D.; Babboni, S.D.; González, G.K.; Giarola, R.M.; Rodrigues, S.A.; Cerqueira, A.T.A.R.; Padovani, C.R.; Victória, C.; Modolo, J.R. Características dos adotantes de cães na área urbana de Botucatu. Veterinária e Zootecnia, 19(4): 584-592, 2012.

Protopopova, A.; Gilmour, A.J.; Weiss, R.H.; Shen, J.Y.; Wynne, C.D.L. The effects of social training and other factors on adoption success of shelter dogs. Applied Animal Behaviour Science, 142(1-2): 61-68, 2012.

Rosa, F. Ainda existe carrocinha em Curitiba? Boato se espalha nas redes sociais. Notícia de 17/02/2017. Disponível em: <http://www.tribunapr.com.br/noticias/curiti ba-regiao/ainda-existe-carrocinha-emcuritiba-boato-se-espalha-nas-redessociais/>. Acesso em: 24 out. 2017.

Santana, L.R.; Oliveira, T.P. Guarda responsável e dignidade dos animais. Revista Brasileira de Direito Animal, 1(1): 67-105, 2006.

Serafini, C.A.V.; Rosa, G.A.; Guimaraes, A.M.S.; Morais, H.A.; Biondo, A.W. Survey of owned feline and canine populations in apartments from a neighborhood in Curitiba, Brazil. Zoonoses Public Health, 55(8-10): 402-405, 2008.

UIPA. União Internacional Protetora dos Animais. História. 2017. Disponível em: <http://www.uipa.org.br/historia/>. Acesso em 18 mai. 2017.

WPA. World Animal Protection. Proteção Animal Mundial. World Animal Protection: datas importantes. 2017. Disponível em: <https://www.worldanimalprotection.org.br/ quem-somos/historia>. Acesso em 18 mai 2017. 